\title{
The policy impact of unified government: evidence from 2000 to 2002
}

\author{
Nathan W. Monroe
}

Received: 28 August 2006 / Accepted: 23 June 2009 / Published online: 14 July 2009

(C) The Author(s) 2009. This article is published with open access at Springerlink.com

\begin{abstract}
Do the outcomes of government action differ between periods of unified and divided government? Using "event study" methodology, this articles addresses the question by looking at sudden shifts between divided and unified government-Bush v. Gore, the Jeffords switch, and the 2002 election. The results show that oil and gas stocks (i.e. Republican "constituent firms") rose abruptly as Republicans took unified control, while renewable energy stocks (i.e. Democratic "constituent firms") fell. The pattern reversed, however, when Democrats took back control of the Senate. These outcomes call into question non-partisan theories of law making.
\end{abstract}

Keywords 2000 U.S. presidential election · Parties and elections · Divided government · Energy policy $\cdot$ Stock market $\cdot$ Event study

\section{Introduction}

The 2000 presidential election was the closest in United States history. Not only was Election Day characterized by great uncertainty over the outcome, but the awarding of Florida's decisive electoral votes delayed the resolution until well into December. When the Supreme Court gave victory to Republican George W. Bush, the United States was faced with the first instance of unified government in six years, and for Republicans, the first in nearly half a century. However, Republican unified control was interrupted a few months later when Senator James Jeffords switched from Republican to Independent, and the Senate back to Democrats, with unified government returning again when Republicans took back the Senate in the 2002 election.

While Republican control was met with great expectations from political pundits, scholarship on the policy process is mixed as to whether these changes between divided and unified government were likely to have had any consequence. The effects of divided control, once taken as common wisdom (Burns 1963; Key 1964; Ripley 1969), have come

N.W. Monroe ( $\varangle)$

University of California, Merced, USA

e-mail: nmonroe2@ucmerced.edu 
under scrutiny from scholars arguing that periods of divided and unified control are better characterized by their overwhelming similarities than their stark differences (Mayhew 1991; Krehbiel 1998; Brady and Volden 1998). Following the lead of Sundquist (1988) and Cutler (1988), others have advanced arguments that cite differences in both congressional policy making (McCubbins 1991; Cox and McCubbins 1991; Lohmann and O'Halloran 1994; Epstein and O'Halloran 1996, 1999; Sundquist 1992; Edwards et al. 1997; Coleman 1999) and presidential bargaining (Kernell 1991; Cameron 2000) under divided control. The question remains: do the outcomes of government action differ between unified and divided government?

Here, I address this debate by looking for the policy impact of changes between divided and unified control of government. To do this, I employ an uncommon methodology, measuring the consequences of unified government in terms of changes in expected policy outcomes. More precisely, using an "event study" research design, I examine the effects of the 2000 election, the Jeffords switch, and the 2002 election on the values of Republican and Democratic "constituent firms." Event studies capture the impact of a given event by measuring changes in the value of relevant market assets, such as common stocks. Relying on the efficient markets hypothesis, this design has the advantage of assessing the immediate reactions of rational investors to new information, rather than waiting weeks, months, or years for policy outcomes to crystallize. Because of the abrupt resolution of uncertainty in the 2000 election, the surprise of Jeffords's switch, and the uncertainty about the outcome of the 2002 Senate elections, I can immediately measure the expected policy impact of these moves between divided and unified government.

Looking at expected policy impact is useful in two ways. First, and most directly, changes in investors' behavior have real, tangible effects in terms of the market values of assets. Thus, where political events - such as changes in control of government-lead investors to dramatically change their valuations of certain stocks, this immediately impacts individuals tied to these markets, sectors, and companies in very concrete ways: money gets made, lost, and shifted in the wake of these events. Second, beyond these direct effects, investors' expectations about future policy (or, rather, the probabilities of future policy changes) can help us test theories of policy making. That is, if we think investors "get it right" in predicting how political changes will affect future policy, then their reactions can serve as valuable signals for scientific testing.

The tests in this paper focus on investor reactions to firms associated with energy policy. By choosing a policy area where Republicans were anxious to change the status quo in a direction favorable to their constituent firms (oil and gas) and unfavorable to Democratic constituent firms (renewable energy), I can test the prediction that Republican majorities in the House and Senate joined forces with a new Republican president to push energy policy in their preferred direction, a plan that was halted once Democrats took back the Senate in May 2001, and was reinvigorated with the 2002 election. The results show that oil and gas stocks rose abruptly with shifts to unified Republican control, but fell when the Democrats took back the Senate, while renewable energy stocks followed the opposite pattern. Certainly, given that the main focus of the paper centers on the first two years of George W. Bush's presidency, we must be cautious in generalizing the conclusions of this analysis. However, the consistent pattern that follows changes in both directions (divided to unified and unified to divided) through three events over a two-year period leads raises substantial concerns about theories that ignore the policy differences between unified and divided government. 


\section{Theories of congressional organization and divided government}

Most commonly, the divided government question is framed as "what are the consequences of divided government?" Implicitly, this focuses us on the veto authority of various actors within the legislative process, including the veto power of the president and of the majority party within the legislative chambers. Indeed, this focus is not without merit. For partisan theories of congressional organization, majority party veto power (also characterized as "negative agenda power," Cox and McCubbins 2002, 2005) is a central component of partisan influence. Similarly, veto power is the central institutional feature of the president's ability to influence public policy. Both Kernell (1991) and Cameron (2000) suggest that the strategic context of presidential power varies greatly depending on which party controls the House and Senate.

While an important power in itself, veto power necessarily implies that there is some positive agenda that is being blocked. Thus, it may be more useful to frame the question as, "what are the consequences of unified government?" Implicitly, positive agenda power-the ability to enact the party agenda (e.g., Rohde 1991; Aldrich 1995)—must also be a tool of the majority party in the legislature if there is a difference between policy under unified and divided control. Indeed, this is particularly important to the extent that parties deliver benefits to their constituencies, especially those in the business sector. Partisan theories imply that with the open avenue of unified government the majority party should change policy in areas where the status quo is ripe for realignment with party interests. Following the 2000 election there were bound to be plenty of status quos that met this description; Republicans had faced either unified Democratic government or divided government for 47 years.

For non-partisan theories of legislative organization, and for those who argue that there is no appreciable difference between policy under divided and unified control, partisan agenda control (both positive and negative) in Congress is absent. As such, whether the president and the Congress are of the same party is immaterial. Mayhew (1991) shows that the number of important laws and executive investigations authorized by the legislative branch does not vary appreciably between unified and divided control. More recently, Krehbiel's (1998) "pivot model" explicitly unifies the congressional organization and divided government debates in advancing the claim that divided government does not affect policy outcomes. Certainly, both theories suggest that the distribution of benefits to partisan constituencies-like firms-should be unrelated to changes in the partisan make-up of Congress and the presidency. But, because the "pivots" certainly changed as a result of the 2000 election, this event does not make for a good test of Krehbiel's model.

Mayhew's theory, however, does imply that policy outcomes should not change when government shifts from divided to unified. Though Mayhew offers evidence only on the enactment of important laws (as well as investigations), the discussion in his conclusion (1991: 179) clearly suggests that his theory is meant to imply that the content of policy should also be relatively unchanged across periods of divided and unified control:

....are there not other ways in which unified as opposed to divided party control might make a significant difference? There are. In closing, five such ways will be introduced here by posing questions and speculating briefly about what their answers might be. In all instances speculation ends in skepticism: Unified versus divided control has probably not made a notable difference during the postwar era.

Thus, the reaction of investors to Bush's election, and the subsequent changes in control of the Senate, allows us to put Mayhew's theory to the test.

Moreover, the events of 2000 to 2002 present an opportunity to pit the predictions of partisan and non-partisan models of the policy process against one another, in that they yield 
different predictions about policy outcomes under unified and divided government. If investors did not adjust their price evaluations of Republican and Democratic firms following these moves in and out of unified Republican control, this would cast doubt on partisan theories; if, however, investor evaluations of firms in the energy industry changed in predictable ways, then there is reason to question non-partisan theories of policy making. Indeed, such changes would not only signal an expected policy difference between periods of unified and divided control, offering support for partisan theories of the policy process, but would also constitute direct evidence of differences in markets across these conditions.

\section{Hypotheses}

Changes in legislative decision-making, and resulting changes in legislative outcomes, can have a variety of consequences. One is a change in the distribution of policy benefits. If the majority party in Congress combines with a like-minded president to pass party-friendly legislation under unified government, then the benefits (or expected benefits) allocated to Democratic and Republican constituents should change with a shift from divided to unified control of government.

Indeed, this should be true even if the presidency is the sole institution to change partisan hands. Given the president's formal veto authority (Cameron 2000) and informal proposal power (Kernell 1986), he can be expected to be both an important adversary to an opposition Congress and an important ally to a Congress of his own party. If the controlling party in Congress would prefer to change status quos that are being protected by an opposition president, then we would expect the election of a new, allied president-as was the case in 2000 - to signal an increase in the probability of change in those status quos.

Though we traditionally think of citizens when we talk about constituents, public policy may have its most direct impact on firms. But changes in legislative decision-making that affect the distribution of policy benefits are likely to affect "constituent firms" even more quickly and directly than constituent citizens. The hypotheses that follow, then, are based on the stock prices of firms that are identified as either Republican or Democratic constituent firms. Indeed, there are plenty of economic players that are tied to partisan fortunes: trial lawyers, unions, pharmaceutical companies, health care providers, educators, and defenserelated manufacturers, just to name a few. But for an event study analysis beginning with the 2000 election, a specific set of conditions needs to be met. The ideal sector should have publicly traded firms (unlike trial lawyers and unions), a relevant policy ripe for change by Republicans (unlike pharmaceuticals and health care), and firms tied to both Republicans and Democrats (unlike defense manufacturers). The energy sector fits the bill perfectly.

One of the central planks of the 2000 Republican platform was a significant change in energy policy. Bush had already outlined a 10-year, $\$ 7.1$ billion proposal, which called for a move back in the direction of reliance on fossil fuels and away from an increasingly developed renewable energy sector. One particular proposal calling for oil and gas drilling in Alaska's Arctic National Wildlife Refuge promised to reap significant rewards for oil and gas companies. These firms were likely to benefit from the change in energy policy proposed by Republicans, at the expense of renewable energy firms.

If partisan theories are correct about the value of unified control of government, then the Supreme Court actions stopping the Florida recount (effectively handing the presidential election to Bush), the Jeffords switch, and the 2002 elections should have affected Republican and Democratic firms in predictable ways. Specifically, 
$\mathbf{H}_{\text {Rep }}$ : The stock prices of oil and gas firms should have increased significantly in reaction to Bush v. Gore and the 2002 elections, and decreased significantly in reaction to the Jeffords switch.

$\mathbf{H}_{\text {Dem }}$ : The stock prices of renewable energy firms should have decreased significantly in reaction to Bush v. Gore and the 2002 elections, and increased significantly in reaction to the Jeffords switch.

These hypotheses are tested under a null hypothesis predicted by non-partisan theories of legislative organization and divided government:

$\mathbf{H}_{\text {Null }}$ : The Bush v. Gore, the Jeffords switch, and the 2002 elections should have had no effect on the stock prices of oil and gas or renewable energy firms.

\section{An event study test of the hypotheses}

Despite their prominence in finance and economics (see MacKinlay 1997 for a review), there are few examples of event studies in political science. ${ }^{1}$ The dependent variable in an event study is the (rate of) return for a given stock or set of stocks. ${ }^{2}$ The return is the change (expressed as a percentage) in the total value of a security, or portfolio of securities, over some period of time (which, in the case of most event studies, is one day). ${ }^{3}$ To test hypotheses, one looks for an event's impact on stock returns during the event window, the day on which the event occurs (or the days surrounding it). To decipher impact, a normal return - the return that would obtain on that day in the absence of any significant event effects - and an abnormal return - which is the difference between the normal return and the actual return-is calculated for each day. The normal return for each day in the event window is estimated by modeling returns of the given stock (or portfolio) across a set of days outside the event window (called the estimation window). Here, this is accomplished by using a "market model" technique (a standard procedure; see Campbell et al. 1997) to control for broad changes in the market, thereby accounting for the possible confounding effects of events that affect the market as a whole.

The critical tests in event studies amount to determining whether the abnormal return is significantly different from zero during the event window. To test for this across a sample of stocks, I employ a time-series, cross-section, generalized least squares (GLS) regression in which the cross-sectional unit is an individual firm's stock and the time series is each day

\footnotetext{
${ }^{1}$ See, e.g., Gilligan and Krehbiel (1988), Gilligan et al. (1990), Roberts (1990a, 1990b), Den Hartog and Monroe (2008) and Schnietz (2003). With few exceptions even event studies that are substantively about law and political science are published in economics or finance journals.

${ }^{2}$ One's first inclination is to render the long-term price level over the weeks and months following the event as the proper measure of an event's impact. But the rapid response of investors to new information as outlined by the efficient markets hypothesis, along with the relationship between the market as a whole and the fortunes of any given stock or sample of stocks, render long-term price level a very poor indicator of the impact of an event on asset values.

${ }^{3}$ More technically, the rate of return is, $\tilde{R}_{i t}=\frac{p(t) \cdot f(t)+d(t)}{p(t-1)}-1$, where $p(t)$ is the last sale price at the end of day $t, f(t)$ is the factor to adjust the price at $t$ (so that the current and previous price are adjusted to account for any "splits," increases in the number of outstanding shares with proportional equity maintained among shareholders), $d(t)$ is the dividend amount, $p(t-1)$ is the sale price of the security at the end of the day.
} 
in the estimation and event windows (Schipper and Thompson 1983; see also Angbazo and Narayanan 1996; Malatesta 1986; McWilliams and Siegel 1997).

The GLS regression model is

$$
\tilde{R}_{i t}=\beta_{i 0}+\beta_{i m} \tilde{R}_{m t}+\beta_{i t} D_{i t}+\tilde{\varepsilon}_{i t}
$$

where $\tilde{R}_{i t}$ is the rate of return for firm $i$ on day $t(i=1,2, \ldots, N)$;

$\tilde{R}_{m t}$ is the rate of return for the market index on day $t ;{ }^{4}$

$D_{i t}$ is a dummy variable equal to one on the day(s) of the event, and zero otherwise; and

$\tilde{\varepsilon}_{i t}$ is an error term (assumed to be normally distributed and serially independent) for firm $i$ on day $t$.

Note that the constant term $\beta_{i 0}$ and the market index term $\beta_{i m} \tilde{R}_{i t}$ jointly constitute the market model, and estimate the normal return. The firm-event dummy term $\beta_{i t} D_{i t}$ then captures any abnormal return for each firm $i$ on the day(s) of the event, which is interpreted as the impact of the event on $i$ 's rate of return. The appropriate test of our hypotheses, then, is to assess the sample-wide effect of each event on the summed $\beta_{i t} \mathrm{~s}, \sum_{i=1}^{N} \beta_{i t}$, to see if they are significant in the predicted direction. ${ }^{5}$

\subsection{Choosing the event window and stock sample for the 2000 election}

To use event study methodology, the "event" needs to have been unanticipated by investors. There is little doubt that the resolution of the 2000 presidential election by the Supreme Court was both surprising and decisive. The U.S. Supreme Court's order stopping the Florida recount, described by the New York Times as "a sudden and devastating blow to Vice President Al Gore's presidential hopes," came less than 24 hours after the Florida Supreme Court had given the Democrats hope by ordering the recount to continue (Greenhouse 2000a). For the 2000 election, there were a number of events - including Election Day itself - that changed the probability of having unified government. Thus, there are a number of days that might be included in our event window. The Supreme Court actions, however, constituted the most abrupt and consequential resolution of uncertainty about the outcome of the election. Accordingly, the event window is constructed around the timing of this event. The events unfolded as follows.

On the afternoon of Saturday, December 9th, the U.S. Supreme Court halted the Florida recount that had restarted just a few hours earlier by order of the Florida Supreme Court. By a five to four vote, the Court agreed to hear Bush's appeal and set oral arguments in the case (Bush v. Gore) for Monday afternoon. This action alone clearly swung the odds significantly in the direction of a Bush victory. However, following the oral arguments on the 11th, there was still some uncertainty as to which way the Court's ruling would go, which was expected as early as the following morning. Though the default seemed to be a 5-4 vote in favor of ending the recount, the "Supreme Court's liberal bloc labored visibly [Monday] to fashion a compromise that might. . .allow the counting of Florida's presidential votes to resume" (Greenhouse 2000b). The justices deliberated late into the night on Monday and all day Tuesday, before reaching a decision late Tuesday night. Their decision, which eliminated the possibility of a recount, and thus a Gore presidency, ended the uncertainty about the 2000 election.

\footnotetext{
${ }^{4}$ For my analysis, I used the CRSP NYSE-AMEX value-weighted index. The results are also robust when using NYSE, AMEX, NASDAQ and S\&P 500 indices.

${ }^{5}$ To test the significance of this term, I use a linear combination test.
} 
Accordingly, I include four event windows. First, each of three trading days-December 11th, 12th, and 13th-after the initial decision to stop the recount on Saturday the 9th are analyzed as separate event windows. Investors would have incorporated information from the events of the weekend on Monday (11th), the oral argument on Tuesday (12th), and the final decision on Wednesday (13th). The fourth event window, which includes all three days together (11th-13th), is intended to capture the impact over the entire period.

There are a number of possible oil and gas firms to include in the analysis. At one extreme, I could include every publicly traded oil and gas firm. This, however, would likely be a very noisy sample. To reduce this noise, I identified those stocks that gave a credible signal that they had a stake in the political process. That is, I identified publicly traded oil and gas firms that, through their corporate PACs, donated money to a candidate for federal office during the 1999-2000 election cycle. ${ }^{6}$ Following standard event study practice, I then excluded firms that had more than two consecutive days of missing data in the Center for Research in Securities Prices (CRSP) database during our time series (the 252 trading days in 2000). ${ }^{7}$ This left 45 firms, including all of the most likely candidates, such as Chevron, Exxon, Halliburton, Kerr McGee, and BP (see Appendix for a full list).

Ideally, renewable energy stocks could have been selected in identical fashion. Unfortunately, this would have left an $N$ of zero, because there were no renewable energy firms associated with corporate PACs during the 1999-2000 election cycle. As such, I run the risk of a potentially noisy signal (which biases the results against rejecting the null hypothesis) by using a sample of all publicly traded renewable energy companies. ${ }^{8}$ After again excluding those firms with more than two consecutive days of missing data during 2000, 14 firms remained, including companies that produce wind energy, hydrogen energy, and water-power. ${ }^{9}$ (See Appendix for a full list.) ${ }^{10}$

\section{Results}

Table 1 presents the results of the tests outlined above. The columns contain GLS coefficients and standard errors, summed across all stocks in the given sample, for both oil and gas and renewable energy stocks for the four event windows just outlined. The $p$-values were produced from linear combination tests of the event dummy coefficients for all stocks in each sample.

The results suggest that investors did indeed react quickly, decisively, and predictably to the Supreme Court actions. On the 11th, the summed abnormal returns for oil and gas

\footnotetext{
${ }^{6}$ To identify "Oil and Gas" corporate PACs, I used the data provided at www.opensecrets.com.

${ }^{7}$ Where there was one or two consecutive days of missing data, I replaced the missing value with a 0 (see Heinkel and Kraus 1988), which implies that the stock value was the same as the day before.

${ }^{8}$ The list of publicly traded renewable energy companies was taken from http://energy.sourceguides.com.

${ }^{9}$ Given the differences in the sizes of the two samples of stocks, one might wonder if there is significant variation in the volatility within them. Looking at a simple measure- the standard deviation of the mean sample return over the estimation window-suggests some difference. The renewable energy sample has a standard deviation of 0.034 while the same measure for the oil and gas sample is just 0.013 . This is expected, and suggests that the renewable sample is less likely to produce significant abnormal returns on any given day.

${ }^{10}$ To account for the possibility of confounding events-that is, other events that could have effected the relevant samples of stocks-I searched online sources of financial news (using the LexisNexis "keyword" option), for events affecting oil and gas or renewable energy stocks from December 9th through December 13th. I found no evidence of contemporaneous events affecting either set of stocks on any of these days.
} 
Table 1 Impact of 2000 presidential election on oil and gas stocks and renewable energy stocks, December 11th-13th, 2000

\begin{tabular}{|c|c|c|c|c|}
\hline & \multicolumn{2}{|c|}{ Oil and gas stocks } & \multicolumn{2}{|c|}{ Renewable energy stocks } \\
\hline & $\begin{array}{l}\sum \text { Coefficients } \\
\text { ( } \text { SE's) }\end{array}$ & $p$-value & $\begin{array}{l}\text { Coefficients } \\
\text { ( } \text { SE's) }\end{array}$ & $p$-value \\
\hline December 11th & $\begin{array}{l}.4333^{* * *} \\
(.1740)\end{array}$ & .01 & $\begin{array}{l}.2110 \\
(.2802)\end{array}$ & .23 \\
\hline December 12th & $\begin{array}{l}.0811 \\
(.1742)\end{array}$ & .32 & $\begin{array}{l}-.4900^{* *} \\
(.2797)\end{array}$ & .04 \\
\hline December 13th & $\begin{array}{l}.0751 \\
(.1742)\end{array}$ & .33 & $\begin{array}{l}-.5363^{* *} \\
(.2799)\end{array}$ & .03 \\
\hline December 11th-13th & $\begin{array}{l}.1442^{*} \\
(.1020)\end{array}$ & .08 & $\begin{array}{l}-.2739^{* *} \\
(.1621)\end{array}$ & .05 \\
\hline
\end{tabular}

\footnotetext{
* Significant at $90 \%$ or greater

** Significant at $95 \%$ or greater

${ }^{* * * *}$ Significant at $99 \%$ or greater. All $p$-values shown are for one-tail tests. Cells contain GLS coefficients and standard errors, summed across all stocks in the given sample. Results for oil and gas are based on a sample of 45 stocks; results for renewable energy are based on a sample of 14 stocks. For each analysis, the estimation window used is the set of all 252 trading days between January 1st and December 31st, 2000
}

firms were highly significant and positive with a $p$-value of 0.01 . This implies that investors quickly made the connection between the increase in the probability of a Bush victory and the long-term value of firms in the oil and gas industry. In immediate terms, this meant an instant increase in wealth to the owners of companies in that sector.

While we cannot reject the null hypothesis for oil and gas firms for either the 12th or 13th (which is unsurprising, given that investors seemed to have incorporated a very high probability of a Bush victory into their trading on Monday), this connection is further reflected in the fourth event window. For December 11th through the 13th, we can reject the null hypothesis of no effect with a $p$-value of 0.08 , in favor of the alternative hypothesis that oil and stock prices rose significantly over that period (though, given the $p$-value here, I would hesitate to draw conclusions from this result independent of the strong result on the 11th).

For renewable energy stocks over the same period, we see a countervailing pattern. Note that unlike the oil and gas stocks, we cannot reject the null hypothesis for the 11th. On both the 12th and the 13th, however, we can reject the null in favor of the alternative hypothesis that renewable energy stocks were negatively and significantly impacted at a $p$-value of 0.05 or better for both days. This result shows up again in the longer event window, measuring the impact of all three days together, where the abnormal returns are negative and significant at better than a $0.05 p$-value.

\subsection{Discussion}

One oddity to explore is that renewable energy stocks took a hit on the 12th and 13th, while oil and gas stocks rose significantly on the 11th. This does not necessarily imply that the market was reacting to something other than the developments in Bush v. Gore. As noted above, no confounding events could be identified for the days in question. Rather, oil and gas stocks were the most obvious benefactors of Republican unified control. Investors would have very quickly adjusted their bids on those stocks in reaction to the greater probability 
of a Bush victory. Renewable energy, however, may not have been so concretely attached to partisan political fortunes. Thus, it may have taken investors longer to adjust their valuations of firms in that sample.

To accept the conclusions of an event study, one must believe that markets are efficient. In the present context, this requires one to believe that investors make good (not perfect, but merely unbiased) predictions about the direction and magnitude of policy change. Given the financial incentives, this seems a reasonable assumption. If it is believed, then market reaction to an event represents a change in expected policy, which in equilibrium represents an unbiased prediction about actual policy effects.

To the reader skeptical of the validity of the link between investor predictions and actual policy, the conclusions drawn here about unified and divided government must be tempered. Still, the results demonstrate a substantial and important effect-a change in real dollars. In those terms, the renewable energy firms in the sample lost more than $\$ 317$ million (7\% of market capitalization) from the 11th to the 13th, while the sampled oil and gas firms gained $\$ 5$ billion (1\% of market capitalization).

For the reader who is inclined to take cues from investor reactions, the findings have additional, significant implications; they lend support to partisan theories of congressional organization and divided government. With status quo energy policy out of line with Republican interests, divided government (and thus a continuing Democratic veto) would mean stability in energy policy, while unified control would mean opening the door for the Republicans in Congress and the White House to move energy policy in their direction. That the resolution of uncertainty over these two possible outcomes (i.e., unified or divided control) was followed by a boost to Republican constituent energy firms and a slump in Democratic firms supports this theoretical account of policy making.

It is difficult, however, to reconcile this market behavior with theories that ignore the influence of parties, and thus do not predict differences in policy outcomes between periods of unified and divided control. Nothing else changed during this brief period that would lead non-partisan theories to predict the observed pattern of change in the prices of oil and gas and renewable energy stocks. In particular, the personnel of the legislature did not change. Not only were the majority parties in the House and Senate already set, but the medians and other pivotal actors in each chamber were already fixed in place.

\subsection{A "Bush effect"?}

Perhaps, though, the reaction of the market was simply a response to Bush's preferences. The new president and vice president were both former oil executives, after all. To the extent that executive branch regulators have significant influence on federal energy policy, we might expect these results even if the story is not about unified versus divided government. Table 2 shows the results of two other relevant event study analyses, this time on oil and gas stocks alone.

The first shows the effect of Senator James Jeffords's decision to switch parties just a few months later, in May 2001, when unified government was changed to divided government due to a change in control of the Senate. ${ }^{11}$ This event study shows a significant and opposite market reaction, of almost identical magnitude to the market response following the resolution of the 2000 election. The next shows the effect on oil and gas stocks of the shift back to

\footnotetext{
${ }^{11}$ For details on the choice of event window, and other issues pertaining to the Jeffords switch, see Den Hartog and Monroe (2008). For a study of public support for divided government, using the Jeffords switch, see Nicholson (2005).
} 
Table 2 Impact of Jeffords's party switch and the 2002 congressional election on oil and gas stocks

Significant at $90 \%$ or greater

** Significant at $95 \%$ or greater

*** Significant at $99 \%$ or greater. All $p$-values shown are for one-tail tests. Cells contain GLS coefficients and standard errors summed across all stocks in the sample. Results are based on a sample of 45 stocks. For the analysis of Jeffords's switch the estimation window used is the set of all 174 trading days between January 1st and

September 10th, 2001

(Den Hartog and Monroe 2008).

For the 2002 analysis, the estimation window used is the 2002 calendar year
Jeffords's switch, 2001

$\overline{\sum \text { Coefficients }} \quad p$-value
$\left(\sum\right.$ SE's)

\begin{tabular}{lll}
\hline May 21st & -.0152 & .460 \\
& $(.1499)$ & \\
May 22nd & $-.3940^{* * *}$ & .004 \\
& $(.1495)$ & \\
May 23rd & $-.2295^{*}$ & .063 \\
& $(.1500)$ & \\
May 24th & $-.2306^{*}$ & .062 \\
May 21st-24th & $(.1495)$ & \\
& $-.2207^{* * *}$ & .002 \\
& $(.0754)$ & \\
\hline & 2002 Election & \\
\hline & $\sum$ Coefficients & \\
\hline Nov 5th & $\left(\sum\right.$ SE's) & .317 \\
Nov 6th & .0673 & .003 \\
Nov 5th-Nov 6th & $(.1409)$ & \\
& $.3960^{* * *}$ & \\
& $(.1495)$ & \\
& $.2319^{* * *}$ & \\
& $(.0996)$ & \\
\hline
\end{tabular}

unified government that followed the 2002 midterm elections, as they experience significant abnormal returns in the positive direction the day after the election. ${ }^{12}$ If the effect of the resolution of the 2000 election was just a "Bush effect", then the fate of oil and gas stocks should not be tied to Republican control of the legislative branch. But the way investors reacted to political events over the two years following the 2000 election, devaluing oil and gas stocks on news of Jeffords's switch and inflating their value as it became clear that Republicans would have unified control of government again in 2003, undermines the notion that the 2000 result is driven by a "Bush effect".

These results suggest that the resolution of the 2000 election in Bush's favor was important for energy policy not because it would have enabled a unilateral change in policy by the president, but because it opened a pathway for Republican action in Congress that would have been closed with divided government under a Gore presidency.

\section{Conclusion}

The tests conducted in this paper imply that investors believe that public policy varies predictably between periods of divided and unified government according to the agenda of the

\footnotetext{
${ }^{12}$ Less can be made of this event study as evidence, since both majority party control of the Senate and, presumably, legislators' preferences changed with the turnover in membership. But the result does suggest that the 2000 oil and gas result is not merely a Bush-only effect.
} 
controlling party. The evidence for this conclusion comes from investor reactions to the actions of Bush v. Gore, the Jeffords switch, and the 2002 election, which established unified Republican government, abruptly took it away, and then reestablished it, respectively. If investor reactions are good proxies for actual expected policy change, then the results have important implications for theories of policy making in the United States. But even for a skeptical reader, the results clearly demonstrate that this change had significant implications for the values of stocks in an important sector of the economy.

It is worth noting that these micro-event level results square nicely with the macro-level analyses and results presented by Leblang and Mukherjee (2005). ${ }^{13}$ That is, they show both formally and empirically that the expectation of lower inflation under right-wing regimessuch as a unified Republican government-leads to a decline in trading volume, and a resulting decrease both in the mean and volatility of stock prices. Thus, their analysis of the last 70 years of the 20th Century offer some suggestive evidence that the results presented in this paper have implications well beyond the two-year window under investigation.

These results also provide insights about other aspects of the political process. First, these findings are a testament to the power of the Supreme Court in the U.S. system. Not only did the Court affect the balance of power at the national level, but it indirectly affected the distribution of wealth in U.S. capital markets. The results also provide strong evidence that oil and gas firms are Republican constituent firms and renewable energy firms are Democratic constituent firms, which sheds new light on the connection between the public and private sectors.

Finally, the results in this paper are encouraging for scholars who have struggled to measure policy impact. The findings suggest that investors $d o$ monitor and react to expected changes in policy, making event studies an excellent option for exploring both the policy impact of political events and the origins of policy change. Indeed, to these ends, the gains in validity, and thus the ability to better establish causality, make event studies not only adequate but in many cases optimal for studying public policy outcomes.

Acknowledgements The author wishes to thank Chris Den Hartog, Mat McCubbins, Jeff Lax, Gary Cox, Gary Jacobson, Allan Timmermann, Cheryl Boudreau, Nick Weller, Lissa Ziegler, Barry Burden, Jonathan Katz, Scott Adler, Carl Snook, Greg Robinson, two anonymous reviewers, and the Public Choice editorial team for helpful comments. The author would also like to thank Maggie Stockel for style and copy-edit assistance.

Open Access This article is distributed under the terms of the Creative Commons Attribution Noncommercial License which permits any noncommercial use, distribution, and reproduction in any medium, provided the original author(s) and source are credited.

\footnotetext{
${ }^{13}$ I refer to Leblang and Mukherjee as a macro-level analysis in reference to the fact that they use a much bigger sample of stocks, (the full sample of the NYSE), look at a much longer period of time (1930-2000), and compare across countries (U.S. and Britain).
} 


\section{Appendix: Companies included in samples}

Oil and Gas Companies

Exxon Mobil Corp.

Peoples Energy Corp.

Chevron Corp.

Sunoco Inc.

Unocal Corp.

USX Marathon Group

AGL Resources Inc.

Enron Corp.

Dynegy Inc.

Halliburton Company

Ashland Inc.

Equitable Resources Inc.

TXU Corp.

Oneok Inc.

National Fuel Gas Co.

Kerr McGee Corp.

Energen Corp.

Questar Corp.

Murphy Oil Corp.

BP Plc.

Occidental Petroleum Corp.

Tesoro Petroleum Corp.

Williams Cos

Nisource Inc.

Apache Corp.

Nicor Inc.

Piedmont Natural Gas Inc.

Dominion Resources Inc.

Anadarko Petroleum Corp.

Burlington Resources Inc.

Cabot Oil \& Gas Corp.

Cross Timbers Royalty Trust

Ultramar Diamond Shamrock Corp.

Torch Energy Royalty Trust

McMoran Exploration Co.

Valero Energy Corp.

El Paso Energy Partners LP

Pennzoil Quaker State Co.

Devon Energy Corp.

Tidewater Inc.
Renewable Energy Companies

Energy Conversion Devices Inc.

Thomas \& Betts Corp.

Honda Motor Ltd.

Spire Corp.

UQM Technologies Inc.

Valence Technology Inc.

Fuelcell Energy Inc.

Exide Corp.

Electric Fuel Corp.

Astropower Inc.

Evercel Inc.

Plug Power Inc.

Bolder Technologies

Real Goods Trading 
Oil and Gas Companies

Renewable Energy Companies

Mitchell Energy \& Dev Corp.

Frontier Oil Corp.

Northwest Natural Gas Co.

Southwest Gas Corp.

Southwestern Energy Co.

\section{References}

Aldrich, J. H. (1995). Why parties? The origin and transformation of party politics in America. Chicago: University of Chicago Press.

Angbazo, L. A., \& Narayanan, R. (1996). Catastrophic shocks in the property-liability industry: evidence on regulatory and contagion effects. Journal of Risk and Insurance, 63, 619-637.

Brady, D. W., \& Volden, C. (1998). Revolving gridlock: politics and policy from Carter to Clinton. Boulder: Westview Press.

Burns, J. M. (1963). The deadlock of democracy. Englewood Cliffs: Prentice Hall.

Cameron, C. M. (2000). Veto bargaining: presidents and the politics of negative power. New York: Cambridge University Press.

Campbell, J. Y., Lo, A. W., \& McKinlay, A. C. (1997). The econometrics of financial markets (1st edn.). Princeton: Princeton University Press.

Coleman, J. J. (1999). Unified government, divided government, and party responsiveness. American Political Science Review, 93(4), 821-835.

Cox, G. W., \& McCubbins, M. D. (1991). Divided control of fiscal policy. In G. W. Cox \& S. Kernell (Eds.), The politics of divided government. Boulder: Westview Press.

Cox, G. W., \& McCubbins, M. D. (2002). Agenda power in the U.S. House of representatives, 1877 to 1986. In D. Brady \& M. D. McCubbins (Eds.), Party, process, and political change in Congress: new perspectives on the history of Congress. Stanford: Stanford University Press.

Cox, G. W., \& McCubbins, M. D. (2005). Setting the agenda: responsible party government in the U.S. House of representatives. New York: Cambridge University Press.

Cutler, L. N. (1988). Some reflections about divided government. Presidential Studies Quarterly, 18, 485492.

Den Hartog, C. F., \& Monroe, N. W. (2008). The value of majority status: the effect of Jeffords's switch on asset prices of republican and democratic firms. Legislative Studies Quarterly, 33, 63-84.

Edwards, G. C. III, Barret, A., \& Peake, J. (1997). The legislative impact of divided government. American Journal of Political Science, 41, 545-563.

Epstein, D., \& O'Halloran, S. (1996). Divide government and the design of administrative procedures: a formal model and empirical test. Journal of Politics, 58, 373-397.

Epstein, D., \& O'Halloran, S. (1999). Delegating powers: a transaction cost politics approach to policy making under separate powers. New York: Cambridge University Press.

Gilligan, T. W., \& Krehbiel, K. (1988). Complex rules and congressional outcomes. Journal of Politics, 50, $625-654$.

Gilligan, T. W., Marshall, W. M., \& Weingast, B. (1990). The economies incidence of the interstate commerce act of 1887: a theoretical and empirical analysis of the short-haul pricing constraint. The Rand Journal of Economics, 21, 189-210.

Greenhouse, L. (2000a). Contesting the vote: the court ruling. New York Times, December 2000, A1.

Greenhouse, L. (2000b). Contesting the vote: the overview. New York Times, 12 December 2000, A1.

Heinkel, R., \& Kraus, A. (1988). Measuring event impacts in thinly traded stocks. The Journal of Financial and Quantitative Analysis, 23, 71-88.

Kernell, S. (1986). Going public: new strategies of presidential leadership. Washington: CQ Press.

Kernell, S. (1991). Facing an opposition congress: the president's strategic circumstance. In G. W. Cox \& S. Kernell (Eds.), The politics of divided government. Boulder: Westview Press.

Key, V. O. Jr. (1964). Politics, parties, and pressure groups. New York: Thomas Y. Cromwell.

Krehbiel, K. (1998). Pivotal politics. Chicago: University of Chicago Press.

Leblang, D., \& Mukherjee, B. (2005). Government partisanship, elections, and the stock market: examining American and British stock returns, 1930-2000. American Journal of Political Science, 49, 780-802.

Lohmann, S., \& O'Halloran, S. (1994). Divided government and U.S. trade policy: theory and evidence. International Organization, 48, 595-632. 
MacKinlay, A. C. (1997). Event studies in economics and finance. Journal of Economic Literature, 35, 1339.

Malatesta, P. H. (1986). Measuring abnormal performance: the event parameter approach using joint generalized least squares. Journal of Financial and Quantitative Analysis, 21, 27-38.

Mayhew, D. R. (1991). Divided we govern: party control, lawmaking, and investigations, 1946-1990. New Haven: Yale University Press.

McCubbins, M. D. (1991). Government on lay-Away: federal spending and deficits under divided party control. In G. W. Cox \& S. Kernell (Eds.), The politics of divided government. Boulder: Westview Press.

McWilliams, A., \& Siegel, D. (1997). Event studies in management research: theoretical and empirical issues. The Academy of Management Journal, 40, 626-657.

Nicholson, S. P. (2005). The Jeffords switch and public support for divided government. British Journal of Political Science, 35, 343-356.

Ripley, R. B. (1969). Majority party leadership in Congress. Boston: Little Brown.

Roberts, B. E. (1990a). A dead senator no lies: seniority and distribution of federal benefits. American Journal of Political Science, 34, 31-58.

Roberts, B. E. (1990b). Political institutions, policy expectations, and the 1980 election: a financial market perspective. American Journal of Political Science, 34, 289-310.

Rohde, D. W. (1991). Parties and leaders in the postreform house. Chicago and London: University of Chicago Press.

Schipper, K., Thompson, R. (1983). The impact of merger related regulations on the shareholders of acquiring firms. Journal of Accounting Research, 24, 184-221.

Schnietz, K. R. (2003). The reaction of private interests to the 1934 Reciprocal Trade Agreements Act. International Organization, 57, 213-233.

Sundquist, J. L. (1988). Needed: a political theory for the new era of coalition government in the United States. Political Science Quarterly, 103, 613-635.

Sundquist, J. L. (1992). Constitutional reform and effective government. Washington: Brookings Institution. 